\title{
Gross anatomy of the stomach and intestine of an antarctic minke whale (Balaenoptera bonaerensis)
}

\author{
Pérez, William ; Lima, Martin ; Büker, Markus ; Clauss, Marcus
}

\begin{abstract}
The gastrointestinal tract of a female, immature (2400 kg body mass, $6.6 \mathrm{~m}$ body length) southern minke whale (Balaenoptera bonaerensis) was investigated. The forestomach had a non-glandular, keratinized squamous epithelium which was separated from the fundic chamber by a clear border between a keratinized epithelium and a glandular, folded mucosa. The beginning of the duodenum consisted of the ampulla duodeni. Both cecum and colon had a smooth external appearance without sacculations or bands. Compared to phylogenetically closely related Artiodactyla, the size of the stomach complex and the intestine was short, corresponding to the carnivorous diet of cetaceans.
\end{abstract}

DOI: https://doi.org/10.1515/mammalia-2015-0168

Posted at the Zurich Open Repository and Archive, University of Zurich ZORA URL: https://doi.org/10.5167/uzh-130378

Journal Article

Published Version

Originally published at:

Pérez, William; Lima, Martin; Büker, Markus; Clauss, Marcus (2017). Gross anatomy of the stomach and intestine of an antarctic minke whale (Balaenoptera bonaerensis). Mammalia, 81(1):111-113.

DOI: https://doi.org/10.1515/mammalia-2015-0168 


\section{Short Note}

William Pérez*, Martin Lima, Markus Büker ${ }^{a}$ and Marcus Clauss

\section{Gross anatomy of the stomach and intestine of an Antarctic minke whale (Balaenoptera bonaerensis)}

DOI 10.1515/mammalia-2015-0168

Received October 25, 2015; accepted December 11, 2015; previously published online February 6, 2016

\begin{abstract}
The gastrointestinal tract of a female, immature (2400 kg body mass, $6.6 \mathrm{~m}$ body length) southern minke whale (Balaenoptera bonaerensis) was investigated. The forestomach had a non-glandular, keratinized squamous epithelium which was separated from the fundic chamber by a clear border between a keratinized epithelium and a glandular, folded mucosa. The beginning of the duodenum consisted of the ampulla duodeni. Both cecum and colon had a smooth external appearance without sacculations or bands. Compared to phylogenetically closely related Artiodactyla, the size of the stomach complex and the intestine was short, corresponding to the carnivorous diet of cetaceans.
\end{abstract}

Keywords: anatomy; cetacean; gut; intestine; stomach.

The digestive anatomy of cetaceans is characterized by a complex stomach compartmentalization (Slijper 1962, Tarpley et al. 1987, Langer 1996, Mead 2007) and, in several species, by particularly long intestinal tracts (Bourdelle and Grassé 1955, Stevens and Hume 1995, Williams et al. 2001). Cetacean stomachs are unique amongst large mammals insofar as the glandular portion of the stomach is subdivided, into the fundic and the pyloric chambers

aPresent address: Tierarztpraxis am Hiddeser Berg,

Gutenbergstr. 26, 32756 Detmold, Germany

*Corresponding author: William Pérez, Área de Anatomía, Facultad de Veterinaria, Universidad de la República, Lasplaces 1620, 11600 Montevideo,Uruguay, e-mail: vetanat@gmail.com

Martin Lima: Área de Anatomía, Facultad de Veterinaria, Universidad de la República, Lasplaces 1620, 11600 Montevideo, Uruguay

Markus Büker and Marcus Clauss: Clinic for Zoo Animals, Exotic Pets and Wildlife, Vetsuisse Faculty, University of Zurich, Winterthurerstr. 260, 8057 Zurich, Switzerland
(Jungklaus 1897), which are connected by a small connecting chamber. Comprehensive data collections on the comparative anatomy on cetaceans are lacking (Büker 2008). Therefore, even isolated data on individual specimens are interesting if they refer to species that have so far not been described.

Here, we used the opportunity to describe the macroscopic digestive anatomy of an Antarctic or southern minke whale (Balaenoptera bonaerensis Burmeister 1867). In contrast to the Northeastern Atlantic minke whale (Balaenoptera acutorostrata Lacepede 1804) for which a dataset on digestive anatomy is available (Olsen et al. 1994), to our knowledge, no such data exist for the southern minke whale; the only information available are the gut content weights reported by Tamura and Konishi (2009).

The gastrointestinal tract of a female southern minke whale was investigated in this study. The animal was found on the beach of Montevideo, Uruguay (34 $52^{\prime} \mathrm{S}$, $\left.56^{\circ} 13^{\prime} \mathrm{W}\right)$. The animal was weighed with a scale of a truck crane and was dissected at the Anatomy Laboratory of the Veterinary Faculty of Montevideo.

After removal from the abdominal cavity, the gastrointestinal tract was measured (and documented by digital photography, see Supplementary material, Figure S1-S4). Stomach contents were measured by weighing the unopened organ and re-weighing it after contents had been rinsed out with water. In addition, the organ was filled with water to its maximum capacity in order to determine the volume. Anatomical measurements were taken following standard procedures. The stomach complex was placed on its left side, and the height and length of the forestomach and the main stomach were made with a soft measuring tape.

The intestinal tract was separated after sectioning the pylorus before the duodenal ampulla. After removal of all mesenteric attachments, the lengths of the different sections of the intestinal tract on the anti-mesenteric side were taken with a standard measuring tape. The full and empty weights of duodenum, jejunum-ileum, cecum, 
colon and rectum were also recorded. We followed the nomenclature of Olsen et al. (1994) and used data from that and other studies for a comparison of our specimen with Northeastern Atlantic minke whales and other cetaceans.

The animal weighed $2400 \mathrm{~kg}$ and had a total body length of $6.66 \mathrm{~m}$, indicating an immature animal (Tamura and Konishi 2009). The stomach complex consisted of the forestomach with a non-glandular, keratinized squamous epithelium (Figure S1), which was separated internally from the fundic chamber by a clear epithelial border between a keratinized epithelium and a glandular, folded mucosa (Figure S2). The folds of this mucosa gradually became smaller towards the connecting chamber with its smooth, glandular epithelium that led into the pyloric chamber that also contained a smooth mucosa and no visible torus pyloricus (Figure S3). The stomach contained $4.0 \mathrm{~kg}$ of contents, had a tissue weight of $9.6 \mathrm{~kg}$, and a water-holding capacity of $70 \mathrm{l}$. While internal connections between chambers generally appeared wide, that of the connecting chamber into the pyloric chamber was, at $11.5 \mathrm{~cm}$ diameter, comparatively narrow. The beginning of the duodenum consisted of the ampulla duodeni. The small intestine measured $35.4 \mathrm{~m}$, had contents of $10.3 \mathrm{~kg}$ and a wet tissue weight of $25.0 \mathrm{~kg}$. The ileum was the terminal part of the small intestine attached to the cecum by the ileocecal fold and opened into the large intestine through the ileal ostium, which was found at the junction of the cecum with the ascending colon. The large intestine was composed of cecum, ascending colon, transverse colon, descending colon and rectum. The cecum measured $39 \mathrm{~cm}$ in length, contained $0.54 \mathrm{~kg}$ contents, and had a tissue weight of $1.3 \mathrm{~kg}$. The colon and rectum measured $3.04 \mathrm{~m}$ in length, contained $1.36 \mathrm{~kg}$ contents, and had a tissue weight of $1.5 \mathrm{~kg}$. Both cecum and colon had a smooth external appearance without sacculations or bands. In contrast to ruminants, the colon was not arranged in a colic coil in the mesentery of the small intestine (Figure S4).

In contrast to large mammalian herbivores that usually have filled digestive tracts when caught in the wild, measures of intestinal contents in cetaceans may be compromised by a prolonged fasting, either due to seasonal and daily feeding habits (Tamura and Konishi 2009) or to the circumstances that led to their capture or stranding. Even in animals hunted in the austral summer season, before the feeding season of the southern minke whale, a large proportion of animals had an empty stomach (Konishi et al. 2014). Nevertheless, even considering only animals with a high stomach fill or the theoretical maximum capacity of the stomach determined by water filling, the stomach capacity of whales appears distinctively less than that observed in herbivorous artiodactyls (Figure 1). This difference is most likely due to the comparatively high digestibility of the cetacean diet (Nordøy et al. 1993, Mårtensson et al. 1994).

Similarly, the length of the digestive tract differs distinctively between herbivorous artiodactyls and baleen whales (Figure 2). From terrestrial mammals, it is well known that herbivores tend to have longer intestines than carnivores of similar body size (Orr 1976). From this perspective, the comparison is hardly surprising. However, both pinnipeds and some cetaceans have particularly long intestines (Stevens and Hume 1995, Williams et al. 2001). For example, a sperm whale (Physeter macrocephalus Linneaus 1758) has, at a body mass of 20-50 tons, intestinal lengths of $150 \mathrm{~m}$ (Slijper 1962). One explanation for the long intestines of many marine mammals is that the intestines are inactive during diving, and that a long intestine therefore compensates for the loss of "digestion time" (Mårtensson et al. 1998). The difference between the deep-diver sperm whale and the shallowdiving krill-eating baleen whales (Figure 2) matches this interpretation.

The maybe most striking difference between the observations of the present study and the anatomical descriptions of Olsen et al. (1994) is the gradual diminishing of the folded glandular mucosa in the fundic chamber; in the previous study, no such gradual transition from the fundic to the connecting chamber was described, nor is it evident from the photographs of that study. One possible

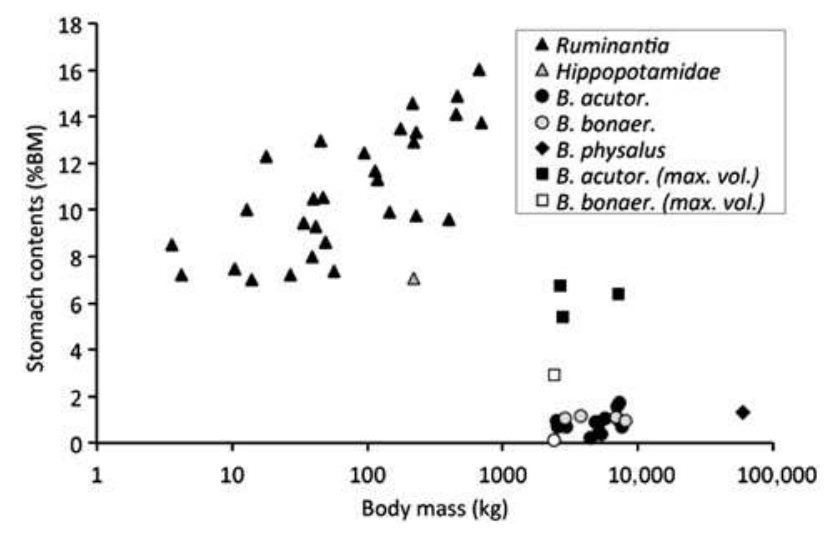

Figure 1: (Fore) stomach wet contents in ruminants (Giesecke and Van Gylswyk 1975, Hoppe 1977, Maloiy et al. 1982), the pygmy hippopotamus (Choeropsis liberiensis Morton 1849) (Schwarm et al. 2010) as a proportion of body mass as compared to data in cetaceans - Balaenoptera bonaerensis (Tamura and Konishi, 2009 and - in white - this study), Balaenoptera acutorostrata (Olsen et al. 1994), Balaenoptera physalus Linnaeus 1758 (Vikingsson 1997). Squares indicate maximum volumes as measured by water fill in B. acutorostrata (Olsen et al. 1994) and B. bonaerensis (this study). 


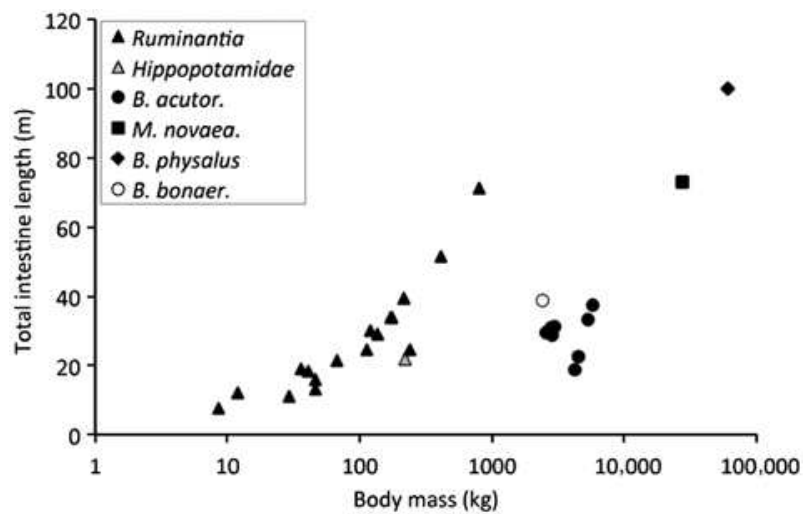

Figure 2: Total intestinal length in ruminants (Woodall and Skinner 1993, Pérez et al. 2009), the pygmy hippopotamus (Choeropsis liberiensis) (Schwarm et al. 2010) and cetaceans - Balaenoptera bonaerensis (this study), Balaenoptera acutorostrata (Olsen et al. 1994), Balaenoptera physalus and Megaptera novaeangliae Borowski 1781 (Slijper 1962). Note the general increase with body mass, but at a higher level in the terrestrial herbivores.

explanation is that the animal of the present study was still comparatively immature and its stomach might not have developed completely. However, the comparatively long intestinal tract of our specimen as compared to Northeastern Atlantic minke whales (Figure 2) could indicate a true species difference.

Acknowledgments: The authors acknowledge Lic. Alberto Ponce de Leon of DINARA and our staff at the anatomy laboratory, especially Virginia Méndez, Alejandra Larrea and Camila Crossa, who worked on the dissection of the whale.

Conflict of interest statement: None declared.

\section{References}

Bourdelle, E. and P.P. Grassé. 1955. Ordre des cétacés. In: (P.P. Grassé, ed) Traité de Zoologie, Anatomie, Systématique, Biologie. Vol. 17. Masson et Cie, Paris, pp. 356-365.

Büker, M. 2008. Literaturübersicht zur Ernährung, Verdauungsanatomie und -physiologie von Meeressäugern (Literature review on nutrition, digestive anatomy and physiology of marine mammals). Dissertation thesis. University of Zurich, Zurich, Switzerland.

Giesecke, D. and N.O. Van Gylswyk. 1975. A study of feeding types and certain rumen functions in six species of South African wild ruminants. J. Agric. Sci. 85: 75-83.

Hoppe, P.P. 1977. Rumen fermentation and body weight in African ruminants. In: (T.J. Peterle, ed.) 13th Congress of Game Biology. The Wildlife Society, Washington, DC, pp. 141-150.
Jungklaus, F. 1897. Die Magen der Cetaceen. Dissertation Thesis, University of Jena, Germany.

Konishi, K., T. Hakamada, H. Kiwada, T. Kitakado and L. Walløe. 2014. Decrease in stomach contents in the Antarctic minke whale (Balaenoptera bonaerensis) in the Southern Ocean. Polar Biol. 37: 205-215.

Langer, P. 1996. Comparative anatomy of the stomach of the Cetacea. Ontogenetic changes involving gastric proportions mesenteries - arteries. Mamm. Biol. 61: 140-154.

Maloiy, G.M.O., C.T. Clemens and J.M.Z. Kamau. 1982. Aspects of digestion and in vitro rumen fermentation rate in six species of East African wild ruminants. J. Zool. 197: 345-353.

Mårtensson, P.E., E.S. Nordøy and A.S. Blix. 1994. Digestibility of krill (Euphausiasuperba and Thysanoessa spp.) in minke whales (Balaenoptera acutorostrata) and crabeater seals (Lobodon carcinophagus). Br. J. Nutr. 72: 713-716.

Mårtensson, P.E., E.S. Nordoy, E.B. Messelt and A.S. Blix. 1998. Gut length, food transit time and diving habit in phocid seals. Polar Biol. 20: 213-217.

Mead, J.G. 2007. Stomach anatomy and use in defining systemic relationships of the Cetacean family Ziphiidae (beaked whales). Anat. Rec. 290: 581-595.

Nordøy, E.S., W. Sørmo and A.S. Blix. 1993. In vitro digestibility of different prey species of minke whales (Balaenoptera acutorostrata). Br. J. Nutr. 70: 485-489.

Olsen, M.A., E.S. Nordøy, A.S. Blix and S.D. Mathiesen. 1994. Functional anatomy of the gastrointestinal system of Northeastern Atlantic minke whales (Balaenoptera acutorostrata). J. Zool. 234: 55-74.

Orr, R.T. 1976. Vertebrate biology. WB Saunders, Philadelphia.

Pérez, W., M. Lima and M. Clauss. 2009. Gross anatomy of the intestine in the giraffe (Giraffa camelopardalis). Anat. Histol. Embryol. 38: 432-435.

Schwarm, A., S. Ortmann, W. Rietschel, R. Kühne, G. Wibbelt and M. Clauss. 2010. Function, size and form of the gastrointestinal tract of the collared Pecari tajacu and white-lipped peccary Tayassu pecari. Eur. J. Wildl. Res. 56: 569-576.

Slijper, E.J. 1962. Whales. Hutchinson, London.

Stevens, C.E. and I.D. Hume. 1995. Comparative physiology of the vertebrate digestive system. Cambridge University Press, New York.

Tamura, T. and K. Konishi. 2009. Feeding habits and prey consumption of Antarctic minke whale (Balaenoptera bonaerensis) in the Southern Ocean. J. Northw. Atl. Fish. Sci. 42: 13-25.

Tarpley, R.J., R.F. Sis, T.F. Albert, L.M. Dalton and J.C. George. 1987. Observations on the anatomy of the stomach and duodenum of the bowhead whale, Balaena mysticetus. Am. J. Anat. 180: 295-322.

Vikingsson, G.A. 1997. Feeding of fin whales (Balaenoptera physalus) off Iceland - diurnal and seasonal variation and possible rates. J. Northw. Atl. Fish. Sci. 22: 77-89.

Williams, T.M., J. Haun, R.W. Davis, L.A. Fuiman and S. Kohin. 2001. A killer appetite: metabolic consequences of carnivory in marine mammals. Comp. Biochem. Physiol. A 129: 785-796.

Woodall, P.F. and J.D. Skinner. 1993. Dimensions of the intestine, diet and faecal water loss in some African antelope. J. Zool. 229: 457-471.

Supplemental Material: The online version of this article (DOI: 10.1515/mammalia-2015-0168) offers supplementary material, available to authorized users. 